\title{
私の最終講義
}

\section{資源, 粉体そしてシステムデザイン}

井上 外志雄*

Toshio INOUE

東京大学工学部鉱山学科を卒業後, 約 37 年の歳月のほ とんどを東京大学工学部で過ごした。卒業研究の表題は 「クラッシャの破壊機構について」であった。この研究 では現場で使われているジャイレートリクラッシャなど の疲労破壊のメカニズムについて調へた。修士論文の テーマは「水中における鉱粒の超音波凝集の機構につい て」であった。この研究では真空管式の超音波発信器を 自作し, 超音波の定在波によって粒子の凝集が起こると いうメカニズムを提起した。

博士課程では「浮遊選鉱プロセスの速度論的研究」を テーマとした。この研究では鉱物粒子の粒度分布や片刃 状態（2 種以上の鉱物が一つの粒子を形成している状 態）が反応速度定数が分布するという考え方を提唱し，

この考え方に基つくく浮選速度過程のモテル化とプロセス 解析の方法は広く受け入れられるものとなった。それと 同時に, 浮選回路の分離特性などの概念を提示したが, 分離過程を始めとする種々のプロセスの成績評価法に関 する基本的な考元方は今も私の研究法の基本になってい ると思う。

選鉱 (mineral processing)* ${ }^{*}$ は元来, 鉱山で採掘さ れた鉱石を物理的手段によって精製するためのプロセス であるが，その一連の過程で最も費用がかかるのは粉砕 と浮選である。そのため多くの研究はこの分野に集中す る傾向にある。私自身もこの領域でいろいろと研究した が, 他にも粒度分布測定装置, 乃過, 沈降濃縮など, 様々なプロセスや装置の研究を手掛けた。若いころ恩師 の今泉常正先生からも伺ったように，選鉱学というのは 大変な雑学であり, 数学, 物理はもとより, 化学, とく に界面化学、鉱物学などが基䃈となっている。さらに機 械，電気などの知識も要求される。うっかりするとこれ らの基礎科学, 基礎工学のつまみ食いをしているうち に，終わってしまう危険さえある。粉体は固体粒子の集 まりであり，粉体プロセスはそれらの粒子の確率的なふ

\section{4年 5 月12日受付}

(厂184 東京都小金井市関野町 1-4-9)

TEL. $0423-83-0747$

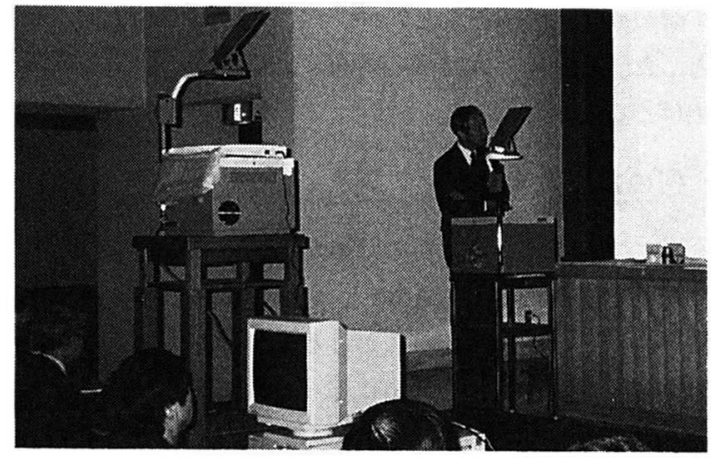

るまいに基ついているので, 確率論をしっかりと勉強 し，その上に立って自分なりの選鉱学を作り上げたいと 発起した時期もあった。研究の対象も, 確率論が応用さ れそうなテーマを意識的に取り上げた中に，オンライン 粒度測定や鉱石のランダム変動之均一化プロセスの研究 がある。粉体プロセスの確率論というとまず頭に浮かぶ のがふるい分けである。私も早速これに飛び付いたが, しばらく研究してわかったことは，ふるい分けというの が極めて非線形性の強いプロセスであるということであ った。海外ではその後, 私にも親しいイタリアの Gian Franco Ferrara 教授が行った研究が有名であるが, 将 来ふるい分けプロセスの本格的な研究にはミクロな視点 が欠かせないと考えているところである。

こうした確率論だけに的を絞った時代もしかし長くは 続かなかった。理由は簡単で, 確率論だけでは収まりき れない問題が次々と目の前に現れたからである。しかし こうした模索の中で, 問題の整理法としてモデルの構築 を研究の要に据えるという姿勢は私なりのモットーとし ていつの間にか定着した。この考えは大学での講義にも 反映され, 学科編成の改革が行われ, 資源開発工学科に 資源システム工学と地球工学というふたつのコースが設 けられたのを機に, 新たなカリキュラムの中でシステム 解析という講義を開設し, その中で決定論的モテルと確 率論的モデルをべースに, 問題の定式化を軸とすること

* : 石炭を対象とする選鉱は選炭（coal preparation）と呼ば れる。 


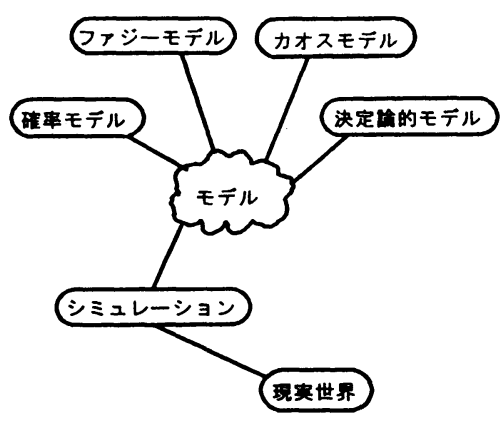

図1種々のモデルとそれらの対象との関係

とした。併せて，大学院の講義ではファジー理論も取り 上げることとした。

\section{何のためのモテリングか？}

ここでモテリングは何のためか，ということについて 立場を明らかにしておきたい。かつては理工学における 研究の主な手段は研究室における実験であった。しかし コンピュータの発達と進歩に伴って, コンピュータが研 究の補助ばかりでなく，実験そのものの手段としても大 いに役立つことが徐々に認識されるようになった。ま た，社会科学や経済学などの分野においては元来, 実験 が困難であり、現象の統計解析などが重要な研究手段で あったが, 近年はその多くに代わって, シミュレーショ ン実験の手法が広く使われるようになっている。

理工学においても，実験には現実の問題を単純化する ことが常套手段となっており，無理な単純化が観察され ろへき真の現象の解釈を歪める結果となっていることも 珍しくない。そこで理工学の研究においても, 現実のプ ロセスをモテル化し，そのシミュレーションによって対 象プロセスの特性を調へることは従来の実験に代わる一 つの有用な研究手法であるといえる。

\section{幾つかのモテル}

選鉱や粉体プロセスのようなシステムあるいは装置の 振舞いを表すモテルとしては従来，物質収支，エネル ギー収支などに着目した状態の時間的変化を常微分方程 式または偏微分方程式によって表す決定論的モデルがも っとも広く使われてきた。また，同じ現象を粒子の確率 的な振舞いによって観察する確率論的モテルも有用であ った。最近ではこれらにファジーモデルやカオスモテル も加わって, シミュレーション実験の手法はさらに充実 の度を增している。

コンピュータによるモテル化の実現においては（少な くとも最終的には）数值化か必須である。コンピュータ 技術の進歩, とくにハードウェアの高性能化によって,
プロセスの全体をマクロに捉えるモデル代わって,一 つ一つの粒子の振舞いに注目したミクロモテルに基つく 数值実験が現実に可能となってきた。ミクロモデルに基 つく数値シミュレーションにおいては, 明確な物理的意 味をもつモテルのコンピュータ上での構築とそのモテル の基礎となっている最小限の実験によって研究を推進す ることができるので，最小のコストで最大の成果を期 待することができる。しかし言うまでもなく大事なのは モテルと素過程がそれぞれ的確に捉えられ，両者が正し く組み合わされていることである。

このような研究方法に対しては批判も少なくない，し ばしば受ける質問は「で、実験結果との対比は行いまし たか?」というものである。この種の質問はシミュレー ションに対する不信に基ついている。確かに数值シミュ レーションにおいては仮定の置きかた, 基本式の形式, パラメーター値の大きさなどによって結果が如何様にも 変化し，何が真実であるかに疑問を投げずにいられない ような場合も少なくない。シミュレーションはコンピ ュータの進歩によって初めて現実のものとなった強力な 道具であると同時にまた，極めて危険な武器でもある。 絽り返すが, 最も大切なのは説得力のある基本モテルと 素過程の正確な評価であろう。

もし，シミュレーションの結果を信じることができ ず, 逐一実験との対比を行わなければいけないというの であれば, シミュレーション実験の真の価値は失われ， 単なる遊びとなってしまう。私は上のような質問にたい して, 次のように答えることにしている。「（シミュ レーションの結果は）現実のプロセスで経験される現象 に合致し、その振舞い, 特性, 意味をよく説明していま す」と。小さな規模で単純化された条件で行われる実験 の結果は、現実のプロセスと大きく遊離していることが 決して少なくない。過去の歴史において，誤った理論や 単純な「基礎」実験によって多くの間違った結論が導か れている。通常の（昔流の）実験かコンピュータシミュ

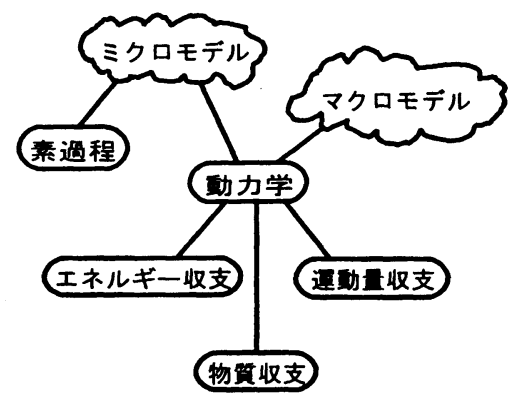

図2プロセスの殾力学に基づくマクロモデルと ミクロモデル 
レーションかによらず，重要なのは対象システムを正し く理解するための洞察力とそれを歪みなく表現しうるモ テルの構筑であることに変わりはない。

\section{これまでの研究の中から}

東京大学でこれまで行ってきた研究としては粒度測 定, 浮選動力学モテル [1], 浮選回路や粉䂶回路の制 御, 鉱石の品質変動之均一化, 沈降分離, 乃過などがあ るが, ここではそれらの中から, マクロモテルおよびミ クロモデによる粉砕回路と粉砝機のシミュレーション ならびに海水ウラン回収システムについて述へることと したい。

\section{1. 粉碚回路のマクロモテル}

ボールミルなどの粉砕機に対する速度論モテルに初め て接したのは Broadbent-Callcott らの論文であっ た。それは大学の学部を卒業し, 大学院に進学して間も ない頃である。この論文をはじめ，その後も引き続いて 海外の学会誌や国際会議などで発表されたこの分野にお ける一連の論文には私の心を強く惹きつけるものがあっ た。この理論の意味, 問題点などを私なりに分析しつ つ，いつか私もこの流儀で粉砕プロセスを、そして粉碎 回路を最適化し，制御することを考えるようになった。

湿式サイクロンを組み合わせたボールミル粉砕回路の 動特性はどのようなものか, 分級性能が変化すると全体 の粉碎効率はどのように変化するか, 分級産物のフィー ドバックによって粉砕回路の安定性はどのように影響さ れるのか, 循環荷重比はどの程度の大きさがよいのかな ど [2]，さらにまたファジー制御あるいはニューラル
ネットワークなどの方法による粉碎回路の制御について も種々研究した。これらの一連の研究ではできるだけ現 実の粉砕回路に近いモデルを構築することを常に心掛 け, ミルの中の流動には拡散混合モテルを使い, また湿 式粉碎の場合、 ミルの中の固体浱度と分級機のフィード の固体湌度をモテル上である設定值に合わせるなどの配 虑をした。このようなモテルで操業条件を変化させる と, ミルの内部での砕料の粒度構成の動的変化に興味あ る現象が見られることなどが分かった。

また，先に触れた鉱石の変動モテルも粉砕その他のプ ロセスモテルに組み合わせることによって, 現実のプロ セスがどのような振舞いを示すかを観察した。

\section{2. 粉碀機のミクロモデル}

このテーマは私にとって東京大学での研究の最後の一 幕となったものである。1993年 5 月，オーストラリアで の国際選鉱会議と私がアジア地区代表を務める国際粉砕 研究連合の第 3 回ワークショップで, ユタ大学の $\mathrm{Raj}$ Rajamani 教授がボールミルの中のボールの動きを離散 要素法（DEM）のモテルで再現し，ボールの衝撃エネ ルギー分布を提示するなど, その研究成果を発表した。 離散要素法は, 最近我が国の粉体工学でも人気が高く, 注目はしていたか， Rajamani の研究発表と彼の好意 で頂いた彼らの一連の研究論文には特に興味深いものが あった。そこで帰国後，以前より興味を持っていた遠心 ミルについてこの手法を適用してみたいと考え, 直ちに 行動を開始した。なお，この研究で極めて短期間に予想 外ともいえる成果を得ることができたのは, 同僚の岡屋 君の馬力もさることながら, 開発言語 FORTH 処理系

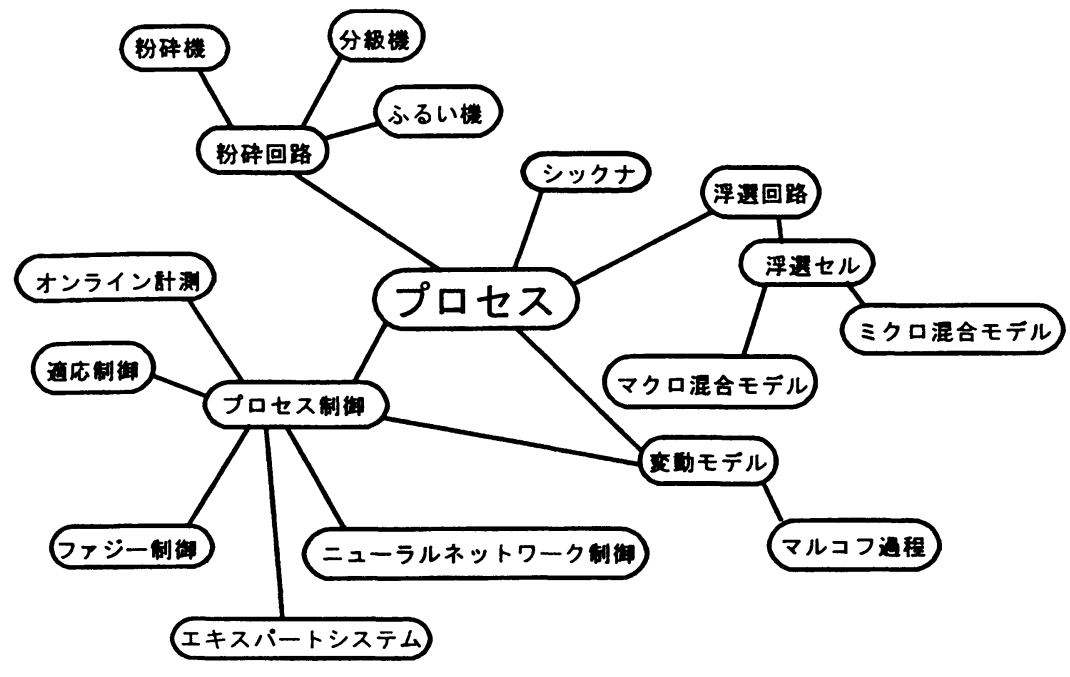

図3私が関った主なプロセスモデル 
の我らが研究室での長年の蓄積によるところも少なくな い。

遠心ミルのDEMシミュレーションについては 5 月の 第 8 回ヨーロッパ粉砕シンポジウムでも発表の予定であ るが, このD E Mプログラムは遠心ミルだけでなく，さ らにボールミル, 振動ミル, 遊星ミルの振舞いも調へらら れるように拡張された。これは至極容易なことであっ た。その結果これらのミルは一つの視点から比較検討さ れることとなる。上記のシンポジウムに引き続いて, ス トックホルム・ヘルシンキ間のフェリーボートの中で第 4 回国際粉砕連合ワークショップが行われることになっ ているので，ここにもコンピュー夕を持ち込み，われわ れのDEMモテルのデモンストレーションを参加者に見 て戴く予定である $[3] 。$

なお, 誤解のないように付け加えるならば, 現在のこ のDEMモデルは粉体粒子一つ一つの振舞い（粉砕現 象）を観察するところまでには至っていない。しかしコ ンピュータの発達は予想を上回る速度で進みつつおり, いずれはもっとミクロな現象がモテル上に展開される時 が来るに相違ない。

\section{3. 海水ウラン回収システム}

昭和 50 年から 10 年余りの歳月をかけて資源エネルギー 庁の委託により，金属鉱業事業団は海水ウラン回収の研 究を行った [4]。この研究には大学・官庁の研究所を はじめ, 大成建設, 三菱金属（現在の三菱マテリア ル), 徳山ソーダ, 旭化成, 三菱化成, 東洋エンジニア リングなどの企業が参加した。私はこの研究に企画段階 より参加し, とくにシステム評価の部分に深くかかわっ た。

海水中には3. $3 \mathrm{ppb}$ という微量のウランが含まれてお り、その資源量はほとんど無尽蔵に近い。研究はこのウ ランを我が国の電力需要の約 $13 \%$ 満たすことを目標と するもので，それだけのウランを採取するには毎秒数万 トンの海水を必要とする計算である。このための設備,

とくに吸着施設は従来の装置産業に類例のない巨大なも のとなり，ウラン採取コストを最低にするシステムの概 念設計が最大の問題となった。システム評価研究の目的 は, ウランの生産コストが最少となるようなシステムの 選択, 条件設定, 研究努力項目の順位付けおよび研究の 進展にともなう効果の推定などであった。

ウラン回収システムの形式としては, 海岸に海水を取 り組むプラントを設け，海水をポンプで汲み込んでウラ ンを選択的に吸着するための吸着剤を充填したベッド （固定床，流動床または移動床）に海水を通過させてウ
ランの一次採取を行う方式 (ポンプカラム方式), ポン プの代わりに潮流を利用する方式，波力を利用する方 式，黒潮などの海流を利用する方式などが検討された が, 結局, 最も実現しやすい方式としてポンプカラム方 式が，また将来の実用プラントとして経済性が期待され る方式として海流利用方式が採択された。これらのいず れの方式においても，チタン酸あるいはアミドキシム樹 脂などの細かな粒状吸着剤を充填した吸着床に海水を通 過させる方法を中心として研究が進められた。

システム評価研究はこのような吸着システムの形態を 想定して行われ，吸着モテルと実験によって定められた 速度パラメ夕に基ついて吸着床の最適厚さ，最適海水流 速, 吸着剤の最適粒径, 一回の吸着日数の最適値などが 評価された。吸着剤の性能, とくに最大ウラン吸着量か 重要と考えられがちであったが，システム評価モテルに よる評価結果では，それはウランの生産コストにさほど 大きな影鳘を持たないことも解った。また，ウランコス トに最も大きな影蠁を及ぼす因子は巨大な吸着施設の建 設費であること，巨大な吸着槽に大量の海水を送り込む ための水路で失われるエネルギーが, 吸着槽自体のエネ ルギー損失よりもはるかに大きくなる可能性が高いこと なども次々と明らかとなった。また，海流利用は他の自 然エネルギー利用方式に比へて最も有利と思われたか， それでも吸着設備の規模がポンプカラム方式に比して大 きくなるため, ウランコストを下げることはかなり困難 であることも分かってきた。

この研究プロジェクトではかつて経験されたことがな い巨大システムの設計に対して，最適化モテルによるシ ステム評価が極めて有用であることを体験することがで きた。

\section{これからの工学研究}

近年工学と理学の境界が次第に薄れつつある傾向にあ る。事実, 理学研究の成果が直接的に工業におけるブ レークスルーに結び付くことも珍しくない。しかし理学 の目標は真理の追究であり，その実用的成果は副産物に すぎないはずである。一方，工学の目的は工業の進歩を 促すことによってわれわれの生活をより快適なものとす ることにあると思う。工学研究の楽しみはその成果が 人々の生活に結び付くということではないだろうか。工 学の研究か「基礎的」研究の美名のもとに工学本来の目 的を見失い，真理の追究はおろか，何の役にも立たない 「研究のための研究」に終わってしまうことを私は強く 鳘戒する。

コンピュータ内蔵の器機が増え, 実験データがコンピ 


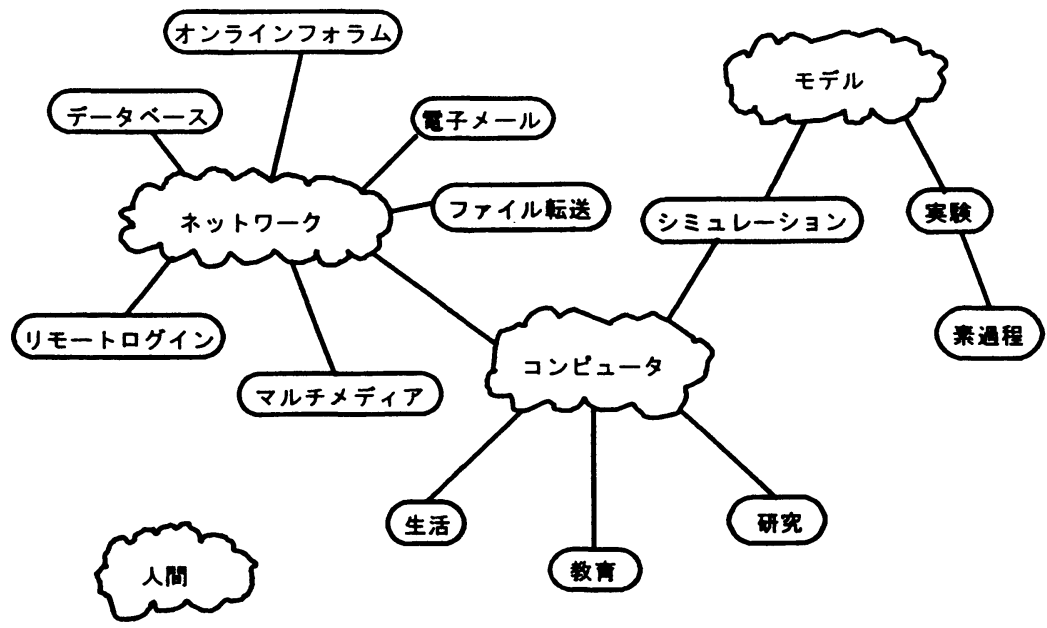

図4私が描く将来の研究桭境

ユータ処理を経て目の前に現れるようになってきた。ブ ラックボックスの中で何が行われ，我々は何を見ている のかに無関心であってはならない。得られたテータが研 究の目的に照らして正しいものでるかどうかを常に問 い正す必要がある。

コンピュータモテリングは新しい工学研究の方法とし て位圈付けられる。しかしそれは極めて強力であると同 時に，現実世界から遊離するや否や，無意味であるばか りか危険極まりない遊戱になってしまう。研究テータを 経験と常識に照らしてチェックすること, 現場経釦に学 ひ、，実世界に対する鋭い観察眼を失わないことが最も重 要であると思う。

過去30数年の私の研究生活において、コンピュータは 私にとって最も大切な道具であったといえる。これから の30年はコンピュータが光ケーブルや人工衛星によって 結ばれ，研究生活にも大きな変化をもたらすこととなろ う。この中で研究情報交換の手段, 学会のありかたなど にも大きな変化が予想される。情報の漏沂が社会主義国 家体制の崩塤を進行させるなど，世界の枠組みも急速に 変わりつつあるが、コンピュータと情報化の時代が地 域，民族，国家のそして個人の格差を拡大することな く，平等化, 民主化への推進力となるよう, 見守って行 く必要がある。

\section{むすひ}

本稿は 2 月16日に東京大学の工学部11号館講堂で行っ た最終請義に基つくか，内容の一部を粉体工学会の会員 向けに変更し, 加筆したものである。16日の請義では私
の研究で大きな部分を占めている浮選速度論についてあ る程度の時間を割いたが，本稿では省いた。また，若い 頃に行った実験やコンピュー夕関係の話も省略した。そ の代りに講義では時間の関係で省略せざるを得なかった 海水ウランの話題を付け加えた。それぞれのテーマの詳 細に触れることは不可能であるか，16日の講義と本稿の 両者を合わせると何とかこれまでの研究の大雑把な維め になっているのではないかと思う。

最後に東京大学での研究に苦楽を共にした学生・ス夕 ッフの諸君および学外からご支援頂いた多くの方々に厚 く御礼申し上げたい。

\section{卷文献}

1.たとえば, T. Imaizumi and T. Inoue "Kinetic Consideration of Froth Flotation, Proceesings," 6 th Int. Mineral Processing Cong., Cannes (1963), T. Inoue : "Flotation Process Modeling. in Principles of Mineral Flotation, "Ed. M. H. Jones and J. T. Woodcock, Aus. IMM (1984)

2. たとえは, T. Inoue and K. Okaya : "Modelling of Grinding Circuits for Simulation Studies, " 4 th Asian Symp. on Mineral Processing, Manila (1994).

3.たとえば, T. Inoue and K. Okaya : "Grinding Mechanism of Centrifugal Mills," 8th European Symp. on Comminution, May 1994, Stockholm.

4.たとえは，金属鉱業事業団講演資料：海水ウラン回 収システム技術確証調查研究成果発表会「海洋溶存 資源とその未来」1988年11月30日 